\title{
Teaching and Learning of 21st Century Learners in Anambra State Secondary Schools: Exploring teacher's preparation and learning environment.
}

\author{
Anekwe, Josephine Uzoamaka \\ Department of Curriculum Studies and Educational Technology, Faculty of Education, University of Port \\ Harcourt, Rivers State, Nigeria.
}

\begin{abstract}
Teaching approaches for the $21^{\text {st }}$ century learners (the netizens) have redefined the roles of teachers in modern classrooms. Therefore, the paper explored the extent of teachers' preparation and appropriate learning environment for effective teaching of requisite skills to $21^{\text {st }}$ century learners. A descriptive survey was adopted. The study was carried out in two education zones in Anambra State, Nigeria. Four research questions and four hypotheses guided the study. Geographical location was taken into consideration for the purposive selection of 10 schools while simple random sampling based on balloting was used for the selection of 2 education zones. Teachers ranks was also considered to select 564 while individual consents were used to select 770 learners. The instruments for data collection were 30 -item questionnaire for teachers and 10-item for learners. The instruments were validated and reliability coefficients were computed to be 0.84 for teachers and 0.80 for students. Data were analyzed using means, standard deviation and rank order for research questions and ttest for hypotheses at 0.05 level of significance. Results showed that teachers' preparation was at a low level and the learning environment was not suitable for $21^{\text {st }}$ century learners. Recommendations were made among which were that secondary school teachers should be trained in line with the $21^{\text {st }}$ century skills and the learning environment should be technologically equipped for challenges of $21^{\text {st }}$ century teaching and learning.
\end{abstract}

Keywords: learning approaches; Netizens; secondary education; $6 \mathrm{Cs} ; 21^{\text {st }}$ century skills.

\section{Introduction}

The relevance of understanding how the $21^{\text {st }}$ century learners learn and how they would prefer to be thought should not be over-emphasized. In Institute for Information Technologies in Education Policy Brief (IITE, 2011), it was categorically stated that the education of yesterdays could not just be applied to the students of tomorrow. This is because, students have changed exponentially and radically, therefore, teachers have to seek for approaches of teaching that are suitable for the digital natives. The digital natives are people who were born into the era of technology, from 1980 till date. The digital natives are also called the netizens. 
The term netizen is in line with the concepts of internet and citizen, just as one is considered, a citizen of the net. A netizen is described as a person who is involved actively in online communities or in the internet generally (Hauben, 1995). For one to be a netizen, one has to be behaving as a citizen of the world to the global connectivity that the net or internet provides. It is considered that everyone that is a netizen is a compatriot with others. A netizen can physically live in Nigeria but is constantly in touch with others in the world through global connectivity networks. By implication, you live very closely to every other individual netizen globally. Separation by geographical location is replaced by existence in the same virtual platforms. The netizens have different characteristics which are quite different from those before them. Also, teaching them takes new directions in order to meet their expectations.

Teaching as cited in Okujagu (2013) viewed teaching as, series of interactions between someone in the role of teacher and someone in the role of a learner, with the explicit goal of changing one or more of the learners' cognitive states. Contributing to the definition, Pollard, Anderson, Maddock, Swaffield, Warin and Warwick (2008) opined that teaching is a complex and highly skilled activity which, in all demands that classroom should exercise judgment in deciding how to act. Joining in this parade is Vedanayagam (1988) cited in Mangal and Mangal (1999) who affirmed that teaching is a scientific process and its major components are content, communication and feedback. From the writer's point of view, teaching involves planning activities systematically and deliberately planned by an individual to facilitate learning of intended knowledge, skills, values and attitude which are worthwhile and get expected feedback. There are commonalities in these definitions and all pointed at the fact that teaching is a complex activity which requires the interactions of both the teacher and the students for effective feedback. It is therefore necessary that those who teach will be fully prepared for the challenges of $21^{\text {st }}$ century teaching.

On the other hand, learning is developmental as new learning builds upon previous learning. Crow and Crow (1973:225) cited in Mangal and Mangal (2009) stated that, "learning is the acquisition of habits, knowledge and attitudes." It implies new ways of doing things and it involves an individual's attempts to overcome hindrances or to adjust to a new situation. To this end, teaching and learning in this $21^{\text {st }}$ century must take into account the constructivist approach, collaborative learning, and networking for learning. The teaching and learning of today do not match with that of the $21^{\text {st }}$ century. Its organization, management, pedagogies, evaluation procedures and the relationship between the netizens, teachers and knowledge they are at odds with the netizens. The secondary school of today is not digitalized, even if it has integrated quite many new technologies (IITE Policy Brief, 2011b). It therefore goes without argument that majority of the teachers are not digital immigrants (Kivunja, 2014) who speak an outdated language (language of pre-digital era).

The digital immigrants are referred to as people born before the advent of the digital age (Prensky, 2001b). They struggle to teach netizens in this $21^{\text {st }}$ century that speak an entirely new language. Kivunja $(2014, \mathrm{~b})$ observed that schools were not helping students to learn. His assertion was based on the fact that the digital natives were being taught by unintelligent digital immigrants that were teaching with a foreign accent that could be difficult to understand by the netizens. 
In teaching the $21^{\text {st }}$ century learners, Ketty, McCain and Jukes (2009) were in support of the ideas buttressed in Prensky (2001b) when they affirmed that, the world we live in has dramatically changed. The present crop of students have moved into the information age. Their learning styles are significantly different. They work, think, and learn differently and our schools and teaching methods are predominantly based on talk and chalk, text books, rote memorization and content based tests are rapidly becoming outdated in the complex society around them.

Based on the above scenario, there is need to investigate the extent to which teachers are prepared for the challenges of teaching the netizens who have clash of interest with their immigrant teachers. By teacher preparation, it is meant to equip the secondary school teachers with the necessary skills, attitudes, values and knowledge required to inculcate into the learners the skills to survive in this computer dominated era and in the field of work. For teachers to function effectively and teach the netizens to learn, they must operate in line with the stipulation of technology standards of International Society for Technology in Education (ISTE) as stated in Lara (2006). The $21^{\text {st }}$ century teachers have to take into account the needs of their students, prepare them so as to be able to face the challenges of future. Teachers are to be trained to have quality professional development program in various modern teaching approaches which must emphasize the use of technology in teaching and in the context (Hafsah, 2017). Based on emerging technologies, the teaching and learning are transforming from teacher-centered, lecture based to student-centered learning environment. Secondary school teachers are supposed to be aware of this truism

Teachers' awareness level of the need to implement $21^{\text {st }}$ century skills of $6 \mathrm{cs}$ at the secondary education is very laudable. The $21^{\text {st }}$ century skills as stated in Miller (2015) are the 6Cs including critical thinking, collaboration, communication, creativity, citizenship/ culture, and character education/connectivity. When teachers are aware of the importance of the netizens to be armed with the $21^{\text {st }}$ century skills, this idea would help them to be working extra miles in teaching and to make sure that learning actually takes place. To achieve this, Tapscott (2009) advocated that $21^{\text {st }}$ century teachers' awareness of 6Cs will help them to prepare their students in the direction of education that is responsive to the educational needs of the digital natives. The awareness of the 6Cs will help in adopting pedagogical approaches including activity-based teaching, individualization of instruction, flipped classroom, problem solving technique, and use of Web 2.0. Specifically, some approaches include that:

- $21^{\text {st }}$ century teachers should prepare learners to develop critical thinking skills;

- teachers should always provide training that encourage students to respond to opportunities and challenges with high speed, agilities and innovations, and inventiveness; and

- teachers should provide training to the netizens that will help them to creatively, critically think and work collaboratively with people of diverse cultures and also among themselves.

In the views of Miller (2015), it was asserted that the first C, Critical Thinking, implies that the students should be able to analyze, filter and logically question all the information they might see and find in their various ways. 
Collaboration implies the diverse ways students could use their talents, personalities, knowledge in order to work together and produce something new.

Communication would imply the ability to put forward ones views, ideas and information clearly, meaningfully and logically. Miller (2015) revealed four main purposes for this which are to inform, instruct, motivate and persuade listeners. The information presented should always be clear, direct, correct and sequential for the listeners to make meaning out of it.

Creativity points to the ability of students to make use of their knowledge and skills to create something new.

Culture is the fifth $\mathrm{C}$ which shows one's ability to showcase and be proud of the way of life of his people anywhere and at anytime. Culture also implies the ability of students to be connected to the things around them, to know and appreciate where they come from, their values and beliefs which their community is known for.

Character or Citizenship Education which is the $6^{\text {th }}$ and last $C$ points to the skill that would enable teachers of $21^{\text {st }}$ century to foster in students the ability to connect globally with their friends and be responsible, civil and capable of contributing as citizens to their communities.

Teachers of the $21^{\text {st }}$ century should understand the relevance of these skills, so as to inculcate them into the $21^{\text {st }}$ century learners. These will in turn mould them to be total and all round individuals in the society in which they live.

To get the above into reality, it is necessary to consider the appropriateness of the learning environment for $21^{\text {st }}$ century teaching and learning. Learning environment implies diverse physical locations, contexts, and cultures in which students learn. The learning environment as stated in (Anekwe, 2004 and Chukwu, 2003) referred to the setting, physical and conceptual methods, media and technology needed to pass information and guide learners' study. The learning environment involves the space and how it is arranged, furnished, routines, materials and equipment, planned and unplanned activities plus people present. The concept also encompasses the culture of the school - its presiding ethos and characteristics, including how individuals interact with and treat one another - as well as the ways in which teachers may organize an educational setting to facilitate learning (Glossary of Educational Reform, 2014).

Learning environment is known to exert powerful influence on human learning and development. This fact was noted in Quisenberry, Eddowes and Robinson (1991) cited in Anekwe (2007). Also, Piaget and Montessori had confessed to the positive effect of favourable environment. For instance, Montessori noted that intelligence is not fixed but can be stimulated or stifled by the learners environment for improved academic achievement. To teach the $21^{\text {st }}$ century learners effectively, the learning environment has to be suited to be in line with global trends, it has to have diverse platform where learners will engage and interact to learn new skills and it has to offer safe platform for learners. Ideally, the learning environment has to have activities that will promote communication and collaborative working. It is therefore necessary to determine the extent to which the learning environment 
in Anambra State secondary schools are in conformity with the $21^{\text {st }}$ century teaching and learning.

Ideally, secondary education is the education provided between primary and tertiary education which is provided for the children who have passed out of the primary schools and also willing to upgrade their school in order to acquire more knowledge and skills to transmit into a world of work or to move to the university or other higher institutions of learning. It is the education offered to teenage learners between 11 to 19 years (Adeyinka, 2016). In the views of Abolade (2000), secondary education is the junction box of all the other levels of education in Nigeria. It accepts pupils from primary education and sends students to the higher levels of education. That shows the relevance of secondary education in Nigeria. Some of the objectives of secondary education in Nigeria as stipulated in the National Policy on Education of Federal Republic of Nigeria (FRN, 2013: 17-18) are to:

- Provide entrepreneurial, technical and vocational job-specific skills for self-reliance, and for agricultural, industrial, commercial and economic development;

- Inspire students with a desire for self-improvement and achievement of excellence; and

- Raise morally upright and well-adjusted individuals who can think independently and rationally, respect the views and feelings of others and appreciate the dignity of labour.

Basically, there are learning approaches which may be preferable to the $21^{\text {st }}$ century learners. Those learners might be highly interested in learning that is engaging, problem-based, learning that provide immediate feedback, interactive games and simulation. Flipped, Goggle classroom and project-based are very necessary for $21^{\text {st }}$ century so as to equip them with skills, knowledge, literacy and expertise that would mould individuals to be successful in work and in daily life (Partnership for $21^{\text {st }}$ Century Skills, 2009). Preparing the digital natives for life-long learning and equipping them with age-appropriate knowledge and skills for survival are among the responsibilities of teaching and learning in $21^{\text {st }}$ century.

\section{Statement of the Problem}

The interest in this research work was triggered by the fact that secondary school leavers in Anambra State, Nigeria, have been seen roaming the street in search of white collar jobs after their graduation instead of being self-reliant and job creators. The result is massive unemployment which has probably led to various social vices in Anambra State. These social vices range from armed robbery operations, cultism and Boko Haram menace and the like. The researcher is therefore uncertain whether these students are equipped with the $21^{\text {st }}$ century skills of $6 \mathrm{cs}$ that prepare the beneficiaries with the education for survival. Hence, this research has set out to explore the extent of teachers' preparation and state of learning environment for preparing learners for $21^{\text {st }}$ century skills. This idea when put in question form is, "what is the extent of teachers' preparation and state of learning environment for $21^{\text {st }}$ century teaching and learning? Providing answers to the aforementioned question is the crux of this study. 


\section{Research Questions}

The underlisted research questions guided the study:

1) To what extent do the secondary school teachers possess the technological skills for teaching the $21^{\text {st }}$ century learners?

2) What is the teachers' awareness level of the need for the $21^{\text {st }}$ century skills implementation at secondary education level?

3) To what extent is the learning environment conducive with technologically-based teaching of $21^{\text {st }}$ century?

4) What are the learning approaches preferable to the $21^{\text {st }}$ century learners?

\section{Hypotheses}

The underlisted four hypotheses were tested at 0.05 level of significance:

1. There is no significant difference in the mean scores of teachers from Onitsha and Ogidi education zones of Anambra State on the secondary school teachers' possession of technological skills for teaching the $21^{\text {st }}$ century learners.

2. The mean responses of teachers from Onitsha and Ogidi education zones of Anambra State on the need for the implementation of $21^{\text {st }}$ century skills of $6 \mathrm{cs}$ at the secondary education level will not differ significantly.

3. There is no significant difference in the mean responses of teachers from Onitsha and Ogidi education zones of Anambra State on the extent to which learning environment is conducive with the $21^{\text {st }}$ century teaching and learning.

4. The mean responses of $21^{\text {st }}$ century learners from Onitsha and Ogidi education zones of Anambra State on the learning approaches preferable to the learners in this $21^{\text {st }}$ century will not differ significantly.

\section{Methodology}

Design: The descriptive survey research design was used for this study using a population of 6090 teachers in Anambra State. From this population, a sample of 611 was used. To draw the sample for the study, two education zones from the state were randomly selected using simple random sampling by balloting. The two Local Governments chosen were Ogidi and Onitsha Education Zones. From Ogidi education zone, a sample of 235 teachers where drawn, while a sample of 329 teachers were drawn from Onitsha Education Zones. The convenient sampling technique was used to draw the teachers from 10 schools each in the two education zones.

Instrumentation: For data collection, a 47-item instrument titled "Skills for $21^{\text {st }}$ Century Teaching Questionnaire" was used. The instrument used for data collection were designed along the research questions and hypotheses guiding the study. The instrument was broadly divided into five section. Section A was designed to elicit information on the demographic characteristics of the respondents, while the remaining four sections were designed to assess the various objectives of the study. The instruments were constructed using the four-point Likert scale format of Very High Extent (VHE), High Extent (HE), Low Extent (LE) and 
Very Low Extent (VLE) which were scored 4, 3, 2 and 1 point(s) respectively. Sections B, C and $E$ which were designed in line with research questions 1,2 and 4 respectively had 10items each, while Section D had 17 items for answering research question 3.

Validation of the instrument was done by subjecting the instrument to expert judgment. The instrument was given to two experts in Educational Measurement and Evaluation, as well as two experts in Educational Technology. Their contributions were integrated into the final version of the instrument before administration. Reliability of the instrument was done using the Cronbach Alpha method. The instrument was administered to 30 teachers who were not part of the target sample in Awka Education Zone of Anambra State. After analysis, an alpha coefficient of 0.78 was obtained, thus indicating that the instrument possessed suitable level of reliability. For data analysis, mean and standard deviation were used to answer the research questions, while independent samples t-test were used to test the corresponding null hypotheses. The results obtained are presented in Tables below.

\section{Result Presentation}

Research Question One: To what extent do secondary school teachers' in Onitsha and Ogidi Educational Zones in Anambra State possess the technological skills for teaching $21^{\text {st }}$ century learners?

Table 1: Mean ( $\overline{\mathrm{x}})$ and Rank Order on the Responses of Teachers in Ogidi and Onitsha Zones on the Possession of Technological Skills for Teaching $21^{\text {st }}$ Century Learners.

\begin{tabular}{|c|c|c|c|c|c|c|c|}
\hline \multirow[t]{2}{*}{$\mathbf{S} / \mathbf{N}$} & \multirow{2}{*}{$\begin{array}{l}\text { Teachers possession of Technological } \\
\text { Skills for } 2^{\text {st }} \text { Century Teaching you } \\
\text { Teach using the following skills: }\end{array}$} & \multicolumn{3}{|c|}{$\begin{array}{l}\text { Onitsha } \\
\mathrm{N}_{1}=329\end{array}$} & \multicolumn{3}{|c|}{$\begin{array}{c}\text { Ogidi } \\
\mathrm{N}_{2}=\mathbf{2 3 5}\end{array}$} \\
\hline & & $\overline{\mathrm{X}}$ & Rank & Remark & $\overline{\mathrm{X}}$ & Rank & Remark \\
\hline 1. & Project-based teaching skills & 2.91 & $6^{\text {th }}$ & $\mathrm{HE}$ & 2.92 & $4^{\text {th }}$ & $\mathrm{HE}$ \\
\hline 2. & Cooperative teaching & 3.05 & $3^{\text {rd }}$ & VHE & 3.03 & $2^{\text {nd }}$ & VHE \\
\hline 3. & Individualization of teaching & 2.95 & $4^{\text {th }}$ & $\mathrm{HE}$ & 2.94 & $3^{\text {rd }}$ & $\mathrm{HE}$ \\
\hline 4. & Activity based teaching & 3.17 & $1^{\text {st }}$ & VHE & 3.11 & $1^{\text {st }}$ & VHE \\
\hline 5. & Flipped classroom skills & 2.65 & $8^{\text {th }}$ & $\mathrm{HE}$ & 2.51 & $8^{\text {th }}$ & $\mathrm{HE}$ \\
\hline 6. & Google classroom & 2.23 & $10^{\text {th }}$ & VLE & 2.24 & $10^{\text {th }}$ & VLE \\
\hline 7. & $\begin{array}{l}\text { Creating and using videos within the } \\
\text { context of lessons }\end{array}$ & 2.88 & $7^{\text {th }}$ & $\mathrm{HE}$ & 2.65 & $7^{\text {th }}$ & $\mathrm{HE}$ \\
\hline 8. & $\begin{array}{l}\text { Electronic productivity devices in the } \\
\text { classroom teaching }\end{array}$ & 2.41 & $9^{\text {th }}$ & LE & 2.41 & $9^{\text {th }}$ & LE \\
\hline 9. & $\begin{array}{l}\text { Assessment based on multiple measures of } \\
\text { students' abilities that include } 21^{\text {st }} \text { century } \\
\text { skills }\end{array}$ & 2.94 & $5^{\text {th }}$ & $\mathrm{HE}$ & 2.71 & $6^{\text {th }}$ & $\mathrm{HE}$ \\
\hline 10. & $\begin{array}{l}\text { Utilization of Web } 2.0 \text { technology to } \\
\text { support collaboration and high order } \\
\text { thinking }\end{array}$ & 3.06 & $2^{\text {nd }}$ & VHE & 2.72 & $5^{\text {th }}$ & $\mathrm{HE}$ \\
\hline & Average & 2.83 & & HE & 2.72 & & HE \\
\hline
\end{tabular}

Results have shown in table 1 indicated that teachers in Onitsha Zones reported mean values which were greater than 2.50, with the exception of item 6 (use of Google Classroom) with a mean value of 2.23 and item 8 (use of electronic productivity devices in classroom teaching) with a mean value of 2.41. Furthermore for teachers in Ogidi, the various skills were possessed to a high extent with the exception of items 6 and 8 which reported mean values of 
2.24 and 2.41 respectively, which were lesser than the chosen criterion mean of 2.50. From the ranking of the various skills possessed, it was shown for both teachers in Ogidi and Onitsha Education Zone, the skills they possessed most is the use of activity based teaching with teachers in Onitsha Zone reporting a mean value of 3.17 and teachers in Ogidi Zone having a mean value of 3.11. However, the least skill possessed for teachers in both Onitsha and Ogidi Zones was use of electronic productivity devices for classroom teaching with reported mean values of 2.23 and 2.24 respectively. From the total mean values, it was shown that teachers in Onitsha Zone had a mean of 2.83 and teachers in Ogidi Zone had a mean of 2.72. These values hereby indicated that teachers in Ontisha Zone had greater skills in teaching technological skills to $21^{\text {st }}$ century learners than teachers in Ogidi Zone.

Research Question Two: What is the awareness level of teachers in Ogidi and Onitsha Education Zones on the need for the implementation of $21^{\text {st }}$ century skills for Secondary School Students?

Table 2: Mean $(\overline{\mathrm{X}})$ and Rank Order on Responses of Teachers in Onitsha and Ogidi Education Zones on the Awareness Level

\begin{tabular}{|c|c|c|c|c|c|c|c|}
\hline \multirow[t]{2}{*}{$\mathbf{S} / \mathbf{N}$} & \multirow{2}{*}{$\begin{array}{l}\text { Teachers Awareness Level. You are } \\
\text { aware of the need for } \\
\text { implementation of the } 21^{\text {st }} \text { century } \\
\text { skills of } 6 \mathrm{cs} \text { as listed below: }\end{array}$} & \multicolumn{3}{|c|}{$\begin{array}{l}\text { Onitsha } \\
\mathrm{N}_{1}=329 \\
\end{array}$} & \multicolumn{3}{|c|}{$\begin{array}{c}\text { Ogidi } \\
\mathbf{N}_{2}=235\end{array}$} \\
\hline & & $\overline{\mathrm{X}}$ & Rank & Remark & $\overline{\mathrm{X}}$ & Rank & Remark \\
\hline 11. & $\begin{array}{l}\text { They are necessary for individuals to be } \\
\text { successful in work and in daily life. }\end{array}$ & 3.54 & $1^{\text {st }}$ & Agreed & 3.45 & $1^{\text {st }}$ & Agreed \\
\hline 12. & $\begin{array}{l}\text { Helps in developing critical thinking } \\
\text { ability. }\end{array}$ & 3.38 & $2^{\text {nd }}$ & Agreed & 3.36 & $2^{\text {nd }}$ & Agreed \\
\hline 13. & Problem solving & 3.32 & $3^{\text {rd }}$ & Agreed & 3.26 & $3^{\text {rd }}$ & Agreed \\
\hline 14. & $\begin{array}{l}\text { Collaboration with people in diverse } \\
\text { areas of life }\end{array}$ & 2.81 & $9^{\text {th }}$ & Agreed & 2.82 & $9^{\text {th }}$ & Agreed \\
\hline 15. & $\begin{array}{l}\text { Leadership for effective life in the } \\
\text { society }\end{array}$ & 2.83 & $8^{\text {th }}$ & Agreed & 2.87 & $10^{\text {th }}$ & Agreed \\
\hline 16. & Entrepreneurship ability & 3.28 & $4^{\text {th }}$ & Agreed & 3.13 & $4^{\text {th }}$ & Agreed \\
\hline 17. & Innovative and inventive ability & 3.25 & $5^{\text {th }}$ & Agreed & 3.19 & $5^{\text {th }}$ & Agreed \\
\hline 18. & $\begin{array}{l}\text { Communicative ability even at global } \\
\text { level }\end{array}$ & 2.31 & $10^{\text {th }}$ & Disagreed & 2.22 & $10^{\text {th }}$ & Disagreed \\
\hline 19. & $\begin{array}{l}\text { Analyzing information in multiple } \\
\text { ways }\end{array}$ & 3.04 & $6^{\text {th }}$ & Agreed & 3.02 & $6^{\text {th }}$ & Agreed \\
\hline \multirow[t]{2}{*}{20.} & Creativity skills for survival & 2.92 & $7^{\text {th }}$ & Agreed & 2.81 & $7^{\text {th }}$ & Agreed \\
\hline & Average & 3.068 & & & 3.013 & & \\
\hline
\end{tabular}

As shown in Table 2 which sought to investigate on the need for the implementation of $21^{\text {st }}$ century skills for public secondary school in Anambra State, teachers in both Onitsha and Ogidi reported that in all the items from the research questions were agreed to a very high level because their mean values were greater than 2.50, with the exception of item 18 for teachers in both educational zones. When the ranking of items was done, it was further shown that the greatest need for the implementation of $21^{\text {st }}$ century education in the secondary school level was for the success of the individual in daily life and the world of work with mean rating of 3.54 for teachers in Onitsha Zone and a mean rating of 3.45 for those in Ogidi Zone, while the least need was from item 18 (communication ability at a global level). Generally, the total mean values from the research questions showed that teachers from Onitsha Education Zone reported a mean of 3.06 while teachers from Ogidi Zone had a mean 
of 2.99. This result indicates that teachers consider the need for the implementation of $21^{\text {st }}$ century skill education as being very important.

Research Question Three: To what extent is the teaching environment conducive for teaching $21^{\text {st }}$ century skills as perceived by secondary school teachers in Ogidi and Onitsha Educational Zones?

Table 3: Mean $(\overline{\mathrm{X}})$ and Rank Order of Teaching Environment for Teaching $21^{\text {st }}$ Century Skills.

\begin{tabular}{|c|c|c|c|c|c|c|c|}
\hline \multirow[t]{2}{*}{$\mathbf{S} / \mathbf{N}$} & \multirow[t]{2}{*}{ Items } & \multicolumn{3}{|c|}{$\begin{array}{l}\text { Onitsha } \\
\mathrm{N}_{1}=329\end{array}$} & \multicolumn{3}{|c|}{$\begin{array}{c}\text { Ogidi } \\
\mathrm{N}_{2}=235\end{array}$} \\
\hline & & $\overline{\mathrm{X}}$ & Rank & Remark & $\overline{\mathrm{X}}$ & Rank & Remark \\
\hline 21. & $\begin{array}{l}\text { Well-equipped building for sports and } \\
\text { games }\end{array}$ & 1.90 & $7^{\text {th }}$ & VLE & 1.61 & $8^{\text {th }}$ & VLE \\
\hline 22. & $\begin{array}{l}\text { Exclusive spaces for learners use on } \\
\text { technological skills and tools. }\end{array}$ & 1.98 & $5^{\text {th }}$ & VLE & 1.59 & $10^{\text {th }}$ & VLE \\
\hline 23. & Physically attractive environment. & 1.94 & $6^{\text {th }}$ & VLE & 1.84 & $4^{\text {th }}$ & VLE \\
\hline 24. & Well ventilated and fully lighted classrooms & 2.09 & $2^{\text {nd }}$ & LE & 2.35 & $1^{\mathrm{st}}$ & LE \\
\hline 25. & $\begin{array}{l}\text { Functional internet connectivity in the } \\
\text { classroom }\end{array}$ & 1.80 & $9^{\text {th }}$ & VLE & 1.70 & $6^{\text {th }}$ & VLE \\
\hline 26. & $\begin{array}{l}\text { Teaching of lessons through interactive } \\
\text { white boards }\end{array}$ & 1.83 & $8^{\text {th }}$ & VLE & 1.81 & $5^{\text {th }}$ & VLE \\
\hline 27. & $\begin{array}{l}\text { Personalized access to computers for each } \\
\text { student }\end{array}$ & 2.00 & $4^{\text {th }}$ & LE & 1.60 & $9^{\text {th }}$ & VLE \\
\hline 28. & Neat and well-arranged school premise & 2.04 & $3^{\text {rd }}$ & LE & 1.91 & $3^{\text {rd }}$ & VLE \\
\hline 29. & Functional computer laboratories & 1.98 & $10^{\text {th }}$ & VLE & 1.68 & $7^{\text {th }}$ & VLE \\
\hline \multirow[t]{2}{*}{30.} & Sense of safety in the school environment & 2.37 & $1^{\text {st }}$ & LE & 2.01 & $2^{\text {nd }}$ & LE \\
\hline & Average & 1.99 & & VLE & 1.81 & & VLE \\
\hline
\end{tabular}

An observation of the mean rating of teachers in Onitsha and Ogidi Educational Zones of the Anambra State revealed that there is a low extent of the provision of conducive learning environment for the teaching and learning of $21^{\text {st }}$ century education. Data analysis showed that with the exception of item 24 (well ventilated and fully lighted classrooms) and item 30 (sense of safety in the school environment), all other environmental indicators were provided to a very low extent. Furthermore, the ranking of the indicators showed that the provision of a sense of safety in the school environment has the highest rating for teachers in both Onitsha and Ogidi Educational Zones. However, for teachers in Onitsha Zone, the provision of functional computer laboratories had the lowest ranking while those in Ogidi Zones rating item 23 (exclusive spaces for learners use on technological skills and tools) as the least. From the result of the grand mean of teachers in Onitsha Zone (1.99) and Ogidi Zone (1.81), the result therefore indicates that there is a low extent to which the environment is conducive for teaching and learning of the $21^{\text {st }}$ century learners in Anambra State.

Research Question Four: What are the learning approaches preferable to $21^{\text {st }}$ century learners in Onitsha and Ogidi Education Zones in Anambra State? 
Table 4: Mean $(\overline{\mathrm{X}})$ and Rank Order on Learning Approaches Preferable to $21^{\text {st }}$ Century Learners

\begin{tabular}{|c|c|c|c|c|c|c|c|}
\hline \multirow[t]{2}{*}{$\mathbf{S} / \mathbf{N}$} & \multirow[t]{2}{*}{ You prefer to learn in the following ways: } & \multicolumn{3}{|c|}{$\begin{array}{l}\text { Onitsha } \\
\mathrm{N}_{1}=329\end{array}$} & \multicolumn{3}{|c|}{$\begin{array}{c}\text { Ogidi } \\
\mathrm{N}_{2}=235\end{array}$} \\
\hline & & $\overline{\mathrm{X}}$ & Rank & Remark & $\overline{\mathrm{X}}$ & Rank & Remark \\
\hline 31. & Having hands and minds in activities & 3.41 & $1^{\text {st }}$ & VHE & 2.75 & $8^{\text {th }}$ & $\mathrm{HE}$ \\
\hline 32. & Problem based learning & 3.05 & $8^{\text {th }}$ & VHE & 3.16 & $3^{\text {rd }}$ & VHE \\
\hline 33. & Collaborative practices & 3.35 & $3^{\text {rd }}$ & VHE & 3.01 & $4^{\text {th }}$ & $\mathrm{HE}$ \\
\hline 34. & Critical based learning & 3.17 & $6^{\text {th }}$ & VHE & 2.67 & $9^{\text {th }}$ & $\mathrm{HE}$ \\
\hline 35. & $\begin{array}{l}\text { When given opportunities to be creative and } \\
\text { innovative }\end{array}$ & 3.16 & $7^{\text {th }}$ & VHE & 3.18 & $2^{\text {nd }}$ & VHE \\
\hline 36. & $\begin{array}{l}\text { Learning that prepares students for } \\
\text { leadership and responsibility skills }\end{array}$ & 2.95 & $9^{\text {th }}$ & $\mathrm{HE}$ & 2.73 & $6^{\text {th }}$ & $\mathrm{HE}$ \\
\hline 37. & Flipped classroom learning & 3.18 & $5^{\text {th }}$ & VHE & 3.19 & $1^{\text {st }}$ & VHE \\
\hline 38. & Project based learning & 3.21 & $4^{\text {th }}$ & VHE & 2.80 & $7^{\text {th }}$ & $\mathrm{HE}$ \\
\hline 39. & Game based learning & 2.20 & $10^{\text {th }}$ & LE & 2.12 & $10^{\text {th }}$ & VLE \\
\hline 40. & Citizenship based learning & 3.36 & $2^{\text {nd }}$ & VHE & 2.81 & $5^{\text {th }}$ & VE \\
\hline & Average & 3.10 & & & 2.84 & & \\
\hline
\end{tabular}

As revealed in Table 4, which focused on the extent to which students reported the preferred learning approach for $21^{\text {st }}$ century skills, it was shown that all the approaches were accepted by students in both Onitsha and Ogidi with mean values of 3.10 and 2.84 respectively. However, it was also shown that game-based learning was not a preferable approach to learning $21^{\text {st }}$ century skills by the students. From the mean values of students in the two educational zones, it was revealed that students in Onitsha Education Zone had a higher mean rating than students in Ogidi Education Zone.

\section{Testing of Hypotheses}

Hypothesis One: There is no significant difference in the mean rating of teachers from Ogidi and Onitsha Education Zones of Anambra State on the technological skills possessed for teaching $21^{\text {st }}$ century skills to secondary school students.

\begin{tabular}{lllllllll}
\hline Location & $\mathbf{N}$ & Mean & SD & df & t-cal & p-value & Alpha & Decision \\
\hline Onitsha & 329 & 2.83 & 0.90 & 564 & 1.42 & 0.16 & 0.05 & $\mathrm{Retain}$ \\
Ogidi & 235 & 2.72 & 0.91 & & & & & $\mathrm{Ho}_{1}$ \\
\hline
\end{tabular}

From the result shown in Table 4, it is shown that when the mean ratings of teachers from Onitsha Education Zone (mean $=2.83, \mathrm{SD}=0.90$ ) and Ogidi Education Zone (mean $=2.72$, $\mathrm{SD}=0.91$ ) were computed on the technological skills they possess for teaching $21^{\text {st }}$ century skills, a t-value of 1.42 was obtained with a corresponding p-value of 0.16 . Since the p-value obtained was greater than 0.05 , it therefore indicates that there is no significant difference in the skills possessed by teachers in Onitsha and Ogidi education zones for teaching $21^{\text {st }}$ century skills in Anambra State. The null hypothesis was therefore retained.

Hypothesis Two: Teachers in Ogidi and Onitsha Education Zones do not differ significantly in their mean ratings on the need for the implementation of $21^{\text {st }}$ century skills teaching for secondary school students. 


\begin{tabular}{lllllllll}
\hline Location & N & Mean & SD & df & t-cal & p-value & Alpha & Decision \\
\hline Onitsha & 329 & 3.068 & 0.93 & 564 & 0.701 & 0.4831 & 0.05 & Retain \\
Ogidi & 235 & 3.013 & 0.90 & & & & $\mathrm{Ho}_{2}$ & \\
\hline
\end{tabular}

From the result shown in Table 6, it is shown that when the mean ratings of teachers from Onitsha Education Zone (mean $=3.06, \mathrm{SD}=0.93$ ) and Ogidi Education Zone (mean $=3.013$, $\mathrm{SD}=0.90$ ) were computed on their perceived need for the implementation of the teaching of $21^{\text {st }}$ century skills in secondary schools, a t-value of 1.701 was obtained with a corresponding $\mathrm{p}$-value of 0.4831 . Since the $\mathrm{p}$-value obtained was greater than 0.05 , it therefore indicates that there is no significant difference in the perception of secondary school teachers on the need for implementing the teaching of $21^{\text {st }}$ century skills in Anambra State. The null hypothesis was therefore retained.

Hypothesis Three: There is no significant difference in the mean ratings of teachers from Onitsha and Ogidi Education Zones on the extent to which learning environment is conducive for teaching and learning of $21^{\text {st }}$ century learners?

\begin{tabular}{lllllcccc}
\hline Location & N & Mean & SD & df & t-cal & p-value & Alpha & Decision \\
\hline Onitsha & 329 & 1.99 & 0.91 & 562 & 2.50 & 0.01 & 0.05 & Reject \\
Ogidi & 235 & 1.81 & 0.73 & $\mathrm{Ho}_{3}$ & \\
\hline
\end{tabular}

The result as shown in Table 7 revealed that when the mean ratings of the teachers in Onitsha and Ogidi Education Zones in the extent to which the learning environment is conducive for teaching and learning of $21^{\text {st }}$ century learners, a t-value of 2.50 was obtained with a corresponding p-value of 0.01 . Since the p-value obtained was lesser than the chosen alpha of 0.05 , it therefore suggested that there is a significant difference between the teachers in Onitsha and Ogidi Zones in the extent to which the learning environment is conducive for teaching and learning of $21^{\text {st }}$ century learners. The null hypothesis was therefore rejected.

Hypothesis Four: The mean responses of students in Onitsha and Ogidi Education Zones of Anambra State do not differ significantly on the preferable approaches for learning $21^{\text {st }}$ century skills.

\begin{tabular}{lllllllll}
\hline Location & N & Mean & SD & df & t-cal & p-value & Alpha & Decision \\
\hline Onitsha & 408 & 3.10 & 0.71 & 564 & 5.10 & 0.0001 & 0.05 & Reject \\
Ogidi & 362 & 2.84 & 0.70 & & & & $\mathrm{Ho}_{4}$ & \\
\hline
\end{tabular}

The result as shown in Table 8 revealed that when the mean ratings of the preferred approaches to learning $21^{\text {st }}$ century skills were assessed in Onitsha and Ogidi Education Zones, a t-value of 5.10 was obtained with a corresponding p-value of 0.0001 . Since the p- 
value obtained was lesser than the chosen alpha of 0.05 , it therefore suggested that there is a significant difference between the approaches preferred by students in Onitsha and Ogidi Education Zone in learning $21^{\text {st }}$ century skills. The null hypothesis was therefore rejected.

\section{Discussion of the Findings}

The study explored teachers' preparation and learning environment for teaching and learning of $21^{\text {st }}$ century learners in both Onitsha and Ogidi Education Zones of Anambra State in Nigeria. The results in Table 1 showed that teachers in these two zones reported that they possessed technological skills to a high extent in almost all the items expect in Google classroom and use of electronic productivity devices in the classroom teachings. Generally, when the rankings of the various technological skills were applied, it was discovered that teachers in Onitsha Zone had greater technological skills in teaching $21^{\text {st }}$ century learners than teachers in Ogidi education zone. In regard to hypothesis one, it indicated that there is no significant difference in the skills possessed by teachers in Onitsha and Ogidi education zones for teaching $21^{\text {st }}$ century skills in Anambra State. The null hypothesis was retained.

The above result was expected based on the fact that Onitsha Zone is considered as a metropolitan city, thickly populated with people from diverse geo-political zones of Nigeria. Majority of the model secondary schools are found in Onitsha Education Zone. Based on these scenarios, teachers with modern techniques in teachings may prefer to dwell in such city. This finding is in line with that found in Garba, Byabazaire and Busthami (2015) who opined that innovative use of technology in teaching-learning process as desired in $21^{\text {st }}$ century learning environment require teachers to have good technological pedagogical knowledge (knowledge of how to integrate technology into teaching) and the skills of its application in teaching the subject content (technological, pedagogical content knowledge, TPC). Their study also revealed that teachers in the rural areas as well as those in urban areas are now acquiring reasonable level of basic ICT literacy skills and competence. In agreement to this finding, Mangal and Mangal (2009) had stated that the possession of digital skills has become the mark of literacy and the application of same in task performance makes lives quite comfortable and purposeful. It is therefore necessary that secondary school teachers acquire the ICT skills for effective delivery of $21^{\text {st }}$ century instruction for no teacher can give out what he has not.

The findings in Table 2 was based on the awareness level of teachers about the need for the implementation of $21^{\text {st }}$ century skills for secondary school learners was investigated in both Onitsha and Ogidi Education Zones, it was discovered that the teachers agreed to a very high level in all the items. In the ranking of the items, it was further revealed that both teachers in Onitsha and Ogidi Education Zones, agreed that the greatest need for the implementation of $21^{\text {st }}$ century skills was for the success of students in daily life and the world of work. The least in the items from both zones was for communication ability at a global level. In all, the two zones considered the need for the implementation of $21^{\text {st }}$ century skills as being very important. With regard to hypothesis 2 , it indicated that there is no significant difference in the perception of secondary school teachers on the need for implementing the teaching of $21^{\text {st }}$ century skills in Anambra State. The null hypothesis was therefore retained. This finding was in consonant with the results of the findings in (Carroll, 2007; Trilling \& Fidel, 2009) and organizations (Partnership for $21^{\text {st }}$ century learning, 2009; and the North Central Regional 
Education Laboratory (NCREL) (2009) and Metiri Group (2006) had attested to the fact that the need to implement the $21^{\text {st }}$ century skills would enable students to acquire the creative thinking, flexible problem solving, collaboration and innovative skills which students will need to be successful in work and life. They strongly emphasized that $21^{\text {st }}$ century learning skills are very critical for the accomplishment of the necessary transformation of schools in $21^{\text {st }}$ century.

Finding in Table 3 in regard to the extent to which teaching environment is conducive for teaching $21^{\text {st }}$ century learners as perceived by teachers in Onitsha and Ogidi Education Zones, it was generally shown that the learning environment was not conducive for the teaching and learning of $21^{\text {st }}$ century learners. From the ranking, the teachers from Onitsha and Ogidi education zones revealed that a sense of safety in school environment was highly appreciated. The result of this finding is not surprising since all the items scored below the acceptable mean of 2.50 like functional internet connectivity in the classroom, personalized access to computers among others.

The above finding is in line with the finding in Garba, Byabazaire and Busthami (2015) who noted that handling the digital natives as learners in schools required a new environment, that is, the $21^{\text {st }}$ century learning environment where the use of technologically-based digital information is at the heart of the learning process. From literature reviewed in their study, it was observed that $21^{\text {st }}$ century teachers should be capable of using technology to engage learners in technology-based learning activities in and outside the classroom. Hence, the present study implies that for a $21^{\text {st }}$ century teaching and learning to be effective, there is need to build a desired and conducive $21^{\text {st }}$ century learning environment for the $21^{\text {st }}$ century netizens. In the writings of Rudite (2017), it was affirmed in line with the expectations of the $21^{\text {st }}$ learning environment that it should be holistic and integrated environment with the goal of providing opportunities for life-long learning and individual study. Some of its characteristics should include: openness and flexibility in terms of time, place, method and the right to study. Anything short of this demands serious improvement to accommodate $21^{\text {st }}$ century learning.

The findings in Table 4 as regards the learning approaches preferable to $21^{\text {st }}$ century learners in the two education zones under investigation showed that all the approaches were accepted except the game-based learning. It was revealed by the respondents that learning approaches like; having hands-and-minds on activities, flexible problem based learning, collaborative, critical, project and flipped classroom learning. On the other hand, the learners did not prefer learning based on games. The null hypothesis 4 showed that there is a significant difference in the approaches preferred by students in Onitsha and Ogidi Education zones in $21^{\text {st }}$ century learning. The null hypothesis was therefore rejected.

The above finding was expected due to the fact that lessons based on games were not commonly used in classes for instructional delivery in Anambra Education Zones. Generally in Anambra State Education Zones, games are used for sports and inter-school competitions but not specifically for classroom instructions. The finding therefore agrees with the result found in Hillary (2016) which stated that the $21^{\text {st }}$ century skills of collaborating and working effectively with others can have a lasting positive impact on individual student learning and increase social competency (Ginsburg-Block, Rohrbeck \& Fantuzzo, 2006). The students 
may have needed to prefer other $21^{\text {st }}$ century skills to game-based learning due to the fact that $21^{\text {st }}$ century skills represent characteristics learners should possess to overcome adversities and achieve successes in education and workplaces. It is also necessary that the relevance of game-based lessons be fully explicated for individual intellectual alertness in $21^{\text {st }}$ century instructional delivery.

\section{Conclusion}

The teaching and learning of the $21^{\text {st }}$ century learners have placed serious demands on teachers to be technologically prepared in order to possess the $21^{\text {st }}$ century skills. The secondary school teachers' possession of these necessary skills will enable them to implement same to the $21^{\text {st }}$ century learners. The teachers are also to be equipped with the skills of appropriate methodologies for implementing the skills of 6cs of critical thinking, creativity, communication, collaboration practices, cultural awareness and citizenship education. Teachers are expected to possess these skills so as to prepare the secondary school learners with education required for survival in this complex society. The justification to technologically equip the secondary school learners with the necessary skills is to fully prepare the learners for self-reliant and for the $21^{\text {st }}$ century work. Teachers cannot give out what they do not have. Therefore, through the implementation of the $6 \mathrm{cs}$, one would have expected that both the teachers and the $21^{\text {st }}$ century learners would build a society devoid of unemployment.

The above expectations and dreams would not come into reality without appropriate and conducive learning environment for effective teaching and learning of $21^{\text {st }}$ century education. The learning environment in this technological era is expected to be structured so as to accommodate diverse teaching and learning approaches. However, it is only when teachers are fully equipped with the necessary skills of $21^{\text {st }}$ century teaching and learning and conducive learning environment provided, our expectation of raising up crop of students who can think, fend for themselves, and contribute actively to the growth and development of their society will be achieved.

\section{Recommendations}

Based on the findings of this study, the following recommendations are made:

1) The secondary school teachers are to be trained so as to enable them in turn teach essential life skills to students which will make them to be gainfully employed after they must have left school. The teachers should be equipped to possess the $21^{\text {st }}$ century skills of $6 \mathrm{cs}$ otherwise, they may still be adopting traditional based teaching and learning.

2) The state government and the Ministry of Education should be organizing awareness campaign on the relevance of implementing the $21^{\text {st }}$ century skills of $6 \mathrm{cs}$ at the secondary education level in Anambra State of Nigeria. This awareness campaign will hopefully spur teachers into action for more hardwork and effective implementation of the $6 \mathrm{cs}$ of $21^{\text {st }}$ century skills.

3) The federal and state governments should join hands together with the nongovernmental organizations in Anambra State to equip the learning environments in secondary schools. This kind gesture will help to promote teaching and learning that 
are in line with the global trends of $6 c s$. Consequently, unemployment will be reduced in our society.

4) The students of secondary schools should be taught to understand the relevance of diverse learning approaches including game-based learning. They should be made to appreciate the fact that each learning strategy has a unique way of moulding an individual into being very productive in the society. Therefore, game-based teaching and learning should be brought as one of the teaching strategies so that students should start to appreciate it.

\section{References}

[1].Abolade, L. R. (2000). The challenges and future of secondary schools students in Nigeria. Multidisciplinary Journal of Research Development, 1(1), 5-10.

[2].Adeyinka, A. A. (2000). Secondary education for what? Reflections on the concept and purpose of secondary education in Nigeria. A Book of Readings in Honour of Israel Olu Osokoga. Ibadan-Nigeria: Laurel Educational Publishers Ltd.

[3]. Anekwe, J. U. (2007). Effect of constructivist-based model on students' interest and academic achievement in French classes in Anambra State secondary schools. Unpublished M.Ed Dissertation of University of Port Harcourt, Rivers State.

[4].Ball, A., Joyce, H.D. \& Anderson-Butcher, D. (2016). Exploring $21^{\text {st }}$ century skills and learning environments for middle school youth. International Journal of School Social Work, 1(1), 1-15.

[5].Carroll, T. (2007). Teaching for the future, Chapter 4 in Building a $21^{\text {st }}$ Century US Education System. National Commission on Teaching and America's Future. http://www.nctaf.org/resources/research_and_reports/nctaf_research_reports/documents/ Chapter4.Carrol.pdf

[6].Chukwu, J. O. (2003). Nursery school environment in Nsukka Urban: A survey. Journal of Curriculum and Practice in Early Childhood Education. Owerri Cape Publishers.

[7].Federal Republic of Nigeria (2013). National policy of education. Lagos: National Educational Research and Development Council Press.

[8].Garba, S.A., Byabazaire, Y. \& Busthami, A.H. (2015). Toward the use of $21^{\text {st }}$ century teaching-learning approaches: The trend of development in Malaysian schools within the context of Asia Pacific. International Journal of Educational Technology, 10(4), 72-79.

[9].Ginsbury-Block, M.D., Rohrbeck, C.A. \& Fantuzzo, J.W. (2006). A mata-analytic review of social, self-concept and behavioural outcomes of peer assisted learning. Journal of Educational Psychology, 98(4), 732-749.

[10]. Hafsah, J. (2017). Teacher of $21^{\text {st }}$ century: Characteristics and development. Research on Humanities and Social Sciences, 7(9), 50-54.

[11]. Hauben, M. F. (1995). The netizens and community networks - presented at the hypernetwork 95 Beppu Bay Conference. Retrieved June 6, 2015.

[12]. Hillary, D. J. (2016). Exploring $21^{\text {st }}$ century skills and learning environment for middle school youth. International Journal of School Social Work, 1(1), 10-25.

[13]. Information Technologies in Education Policy Brief (IITE, 2011). Digital natives: How do they learn? How to teach them? UNESCO Institute for Information Technologies in Education. 
[14]. Kelly, F.S., McCain, T. \& Jukes, I. (2009). Teaching the digital generation. No more cookie - cutter high schools. Melbourne, Vic: Hawker Brownlow Education.

[15]. Kivunja, C. (2014). Theoretical perspectives of how digital natives learn. International Journal of Higher Education, 3(1), 94-107.

[16]. Lara, S. (2006). Preparing teachers and schools for the $21^{\text {st }}$ century in the integration of information and communication technologies. Review of Recent Report in the U.S.

[17]. Mangal, S.K. \& Mangal, U. (2009). Essentials of educational technology. New Delhi: PHI Learning Private Limited.

[18]. Metiri Group (2006). Technology in schools: What the research says? Commissioned by Cisco Systems. Retrieved April 1, 2010 from http://www.cisco.com/web/strategy/docs/ education/technologyinschoolsreport.pdf

[19]. Miller, B.S. (2015). The 6Cs squared version of education in the $21^{\text {st }}$ century. www.bamradionetwork.com. Retrieved on July 26, 2018.

[20]. NCREL \& Metiri Group (2003). enGauge $21^{\text {st }}$ century skills: Literacy in the digital age.

[21]. Okujagu, A.A. (2013). Teacher preparation and vision 20:2020: Challenges ahead. Mediterranean Journal of Social Sciences, 4(5), 81-87.

[22]. Partnership for $21^{\text {st }}$ Century Skills (2009). P21 framework definitions. Retrieved from http://www.p21.org/storage/documents/P21_framework_definitions.pdf.

[23]. Pollard, A., Anderson, J., Maddock, N., Swaffield, S., Warin, J., Warwick, P. (2008). Reflective teaching ( $3^{\text {rd }}$ Ed.). London: Continuum International Publishing Group.

[24]. Prensky, M. (2001). Digital natives, digital immigrants. Part 1. On the Horizon, 9(5), 3-6, http://dx.doi.org/10.1108/10748120110424816.

[25]. Quisenberry, J., Eddowes, A. \& Robinson, S.L. (1991). Readings from childhood education. Association for Childhood Education International.

[26]. Tapscott, D. (2009). Grow up digital: How net generation is changing your world. New York: McGraw-Hill.

[27]. The Glossary of Educational Reform (2014). Culture. Retrieved from https://www.edglossary.org/school-culture/.

[28]. Trilling, B., \& Fadel, C. (2009). 21st century skills: Learning for life in our times. Jossey-Bass. 